Doi: HTTPS://DOI.ORG/10.23910/2/2020.0372

\title{
Factors Affecting Entrepreneurial Intention of Students in Agricultural Sector
}

\author{
Apoorva Sahni ${ }^{*}$, Yasmin Janjhua and Krishan Kumar Sharma
}

Department of Business Management, College of Horticulture, Dr. Y. S. Parmar University of Horticulture and Forestry, Nauni, Solan, Himachal Pradesh (173230), India

\section{Corresponding Author}

Apoorva Sahni

e-mail: apurvasahni7@gmail.com

\author{
Article History \\ Article ID: IJEP0372 \\ Received in $31^{\text {st }}$ March, 2020 \\ Received in revised form $16^{\text {th }}$ June, 2020 \\ Accepted in final form $06^{\text {th }}$ July, 2020
}

\begin{abstract}
India being an agrarian country, with tremendous natural resources, agricultural sector of the country is a potential business area to be developed by youth. Agricultural sector can be enhanced more through agripreneurial activities. This study provides an insight into the factors that have an effect on the entrepreneurship intention of agricultural students. It would serve as base for future studies and have implications for educators and policy makers.
\end{abstract}

Keywords: Agriculture, behavioural control, entrepreneurship, intention, subjective norms

\section{Introduction}

Entrepreneurship has been becoming progressively crucial. It helps in making of a society and is an integral part of economic development. It is that weapon that helps combat unemployment, generates productivity, and help achieve innovative and competitive dominance. Entrepreneurship is one of the alternatives that has been alluded to as a factor that has a positive effect on economic growth (Urbano et al., 2018). Various researchers have measured the entrepreneurial intention in different contexts and tried to determine the factors that have an impact on the said intention. Since education offered by university mostly influences the career selection of students, universities can be seen as the potential sources of nascent entrepreneurs (Turker and Selcuk, 2009; Ambad and Damit, 2016).

People do not engage in entrepreneurship by accident or by chance, they do it intentionally as a result of choice (Krueger, 2007). Entrepreneurial intention is a determinant element to perform entrepreneurial behaviour (Pribadi, 2005). It is a state of mind which directs and guides the actions of individuals towards the development and implementation of new business concepts and innovative ideas (Bird, 1988). Ajzen (1991) considered intention as an indication of the degree of effort an individual or group is willing to put up to execute a particular behaviour. According to Bird (1988) entrepreneurial intention is basically development of a new venture or recreation of possibilities, values and parameters in ventures already in operation.
Agripreneurial intention refers to the intention of an individual to indulge in entrepreneurship in agricultural sector. Agripreneurship activities involve making profitable income by commercializing agriculture products from activities like farming, planting, fisheries, and animal husbandries. Agripreneurial intention or entrepreneurial intention of agricultural students is influenced by various factors, internal and external. In an agrarian economy, it is important to understand the influence and impact of these factors so that a successful agripreneurship work culture can be developed. Mohamed et al. (2012) concluded training and inculcating agripreneurship work atmosphere as the engines for agripreneurship development among young graduates.

\section{Intention Models}

To explore the factors that influence the entrepreneurial intention (EI) of individuals, various scholars have introduced several theoretical models. The models of Ajzen (1991) and Shapero (1984) have been robustly tested and validated by existing literature (Peterman and Kennedy, 2003; Guerrero et al., 2008; Krueger et al., 2000; Kolvereid, 1996; Tkachev and Kolvereid, 1999). These models present the basic cognitive linkage from the antecedents of EI to El itself and to entrepreneurial action (Figure 1).

The theory of planned behaviour (TPB) was introduced by Ajzen (1991). TPB consists of three components that predict the formation of intention, namely (1) the attitude toward the behaviour, (2) subjective norms and (3) the degree of 


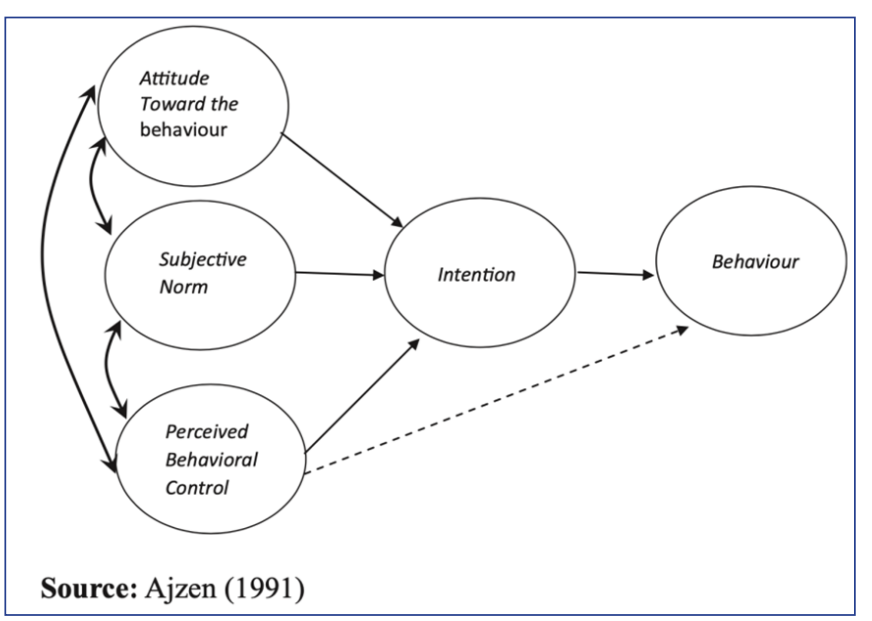

Figure 1: Factors influencing the entrepreneurial intention (EI) of individuals

perceived behavioural control (self-efficacy). The attitude toward the behaviour is the attractiveness of the behaviour or the degree to which the individual holds a positive or negative personal valuation of entrepreneurship (Ajzen, 1991). It is equivalent to the perception of the personal desirability of the behaviour in Shapero's model (Zhang et al., 2014). Subjective norms measure the perceived social pressure from family, friends, or significant others (Ajzen, 1991), referring to people's perceptions of a particular behaviour. This includes the family's expectation for an individual's behaviour and the expected support from other significant people. Perceived behavioural control refers to the perception of situational competence and reflects the perceived ability to become self-employed. It is called selfefficacy by Bandura (1997) and is equivalent to perceived feasibility in Shapero's model.

\section{Factors Affecting Agripreneurial Intention}

\subsection{Attitude towards behaviour}

Various studies found that attitude toward the behaviour is an influential variable in young entrepreneur's intention in agricultural sector (Zampetakis et al., 2014; Devi, 2015). In similar vein, Saheed and Kavoos (2016) concluded that youth entrepreneurship in Africa had positive attitude and were ready to take risks and standalone. On same track, intentions of youth entrepreneurship in Chinai agricultural sector was found to be influenced by the attitude factor (Devi, 2015). On the other hand, Arisandi (2016), Ridha et al. (2016) found no such affect of attitude on entrepreneurial intentions of students in the agricultural sector. 3.2. Subjective norms

Shiri et al. (2012) and Ridha et al. (2016) in their studies found that subjective norm had a significant effect on young students that had an educational background in agriculture. Another study conducted in Indonesia by Arisandi (2016) suggested that entrepreneurial intentions of agricultural sector students at Bogor agricultural University were influenced by subjective norm. Similar results were found by Wijerathna (2015), concluding that subjective norms and attitudes significantly influenced entrepreneurial intentions of agricultural students in Sri Lanka.

\subsection{Perceived behavioural control}

Some authors found that attitude, subjective norms, perceived behavioural control were highly correlated with entrepreneurial intentions of agricultural students (Masoomi et al., 2016). Likewise, Muhammad et al., (2015); Shiri et al. (2017) found that attitude, subjective norm and control behaviour power all together influence the entrepreneurial intention of students. While, Arisandi (2016), Ridha et al. (2016) in their study found that behavioural control perceived no effect on entrepreneurial intentions of students in the agricultural sector.

\subsection{Proactiveness}

Yusoff et al. (2016) found that agricultural graduates' intention to become agripreneurs was substantially influenced by proactive orientation and agripreneurship education (AE). While, no support was found for risk taking and $\mathrm{AE}$ and innovativeness and $\mathrm{AE}$.

\subsection{Agricultural education and entrepreneurship education}

Zampetakis et al. (2014) through his study found that educational background in agriculture highly affected agripreneurship intention of the students. On similar lines, Mohamed et al. (2012) found that respondents with agriculture background were more likely to become agrientrepreneurs as compared to the ones with social science background. Pouratashi (2014) also found that education support (entrepreneurship courses), skills and personality traits were the three factors that influence entrepreneurial intentions of agricultural students. Studies have found that a significant relationship exists between agripreneurship education and agripreneurship intention (Yusoff et al., 2016). While, Aziz and Naem (2013) found that education background had no significant affect on entrepreneurship intention of students in agriculture context.

\subsection{Educational level}

Mohavedi et al. (2013) found that bachelor candidates were more inclined to work in agricultural sector.

\subsection{Role model}

Shiri et al. (2017) through their study concluded that having a role model had a strong impact on entrepreneurial intention through effects of perceived behavioural control, subjective norm and attitude.

\subsection{Parents employment status}

Pouratashi (2014) found significant differences between students who had self- employed parents and who had not on the basis of entrepreneurial intentions, in which agricultural students with self-employed parents had significantly more intention for self employment than their counterparts. 


\section{Conclusion}

An integration of agriculture sector and entrepreneurship would direct nation towards development, ease employment pressure and serve the economy. This review revealed that intention in agricultural entrepreneurship is influenced through various factors like attitude, relational support, behavioural control, personality factors, education, role models, parents occupation. An escalation of research in this domain will eventually help is formulating more effective education initiatives and provide an aid to the policy makers.

\section{References}

Ajzen, I., 1991. The theory of planned behaviour. Organizational behaviour and human decision process 50, 179-211.

Ambad, S.N.A., Damit, D.H.D.A., 2016. Determinants of entrepreneurial intention among undergraduate students in Malaysia. Procedia Economics and Finance 37, 108-114.

Arisandi, D., 2016. Intensi Berwirausaha Mahasiswa Pascasarjana Institut Pertanian Bogor Pada Bidang Agribisnis (Studi Kasus Pada Mahasiswa Program Magister Sps-Ipb), Thesis, Bogor Agricultural University, Bogor, ID. Intention in agricultural sector.

Aziz, A., Naem, N., 2013. Factors that influence the interest of youths in agricultural entrepreneurship. International Journal of Business and Social Science 4, 288-302.

Bandura, A., 1997. Social learning theory. Englewood Cliffs, NJ: Prentice Hall.

Bird, B., 1988. Implementing entrepreneurial ideas: The case for intention. Academy of Management Review 13, 442-453.

Devi, M., 2015. A study on the influencing factors for a literate youth to take up agricultural entrepreneurship. International Journal of Management and Commerce Innovations 3, 692-700.

Guerrero, M., Rialp, J., Urbano, D., 2008. The impact of desirability and feasibility on entrepreneurial intentions: a structural equation model. International Entrepreneurship and Management Journal 4, 35-50.

Kolvereid, L., 1996. Prediction of employment status choice intentions. Entrepreneurship Theory and Practice 21, 47-57.

Krueger, N.F., 2007. What Lies Beneath? The Experiential Essence of Entrepreneurial Thinking. Entrepreneurship Theory and Practice 31, 123-138.

Krueger, N.F., Reilly, M.D., Carsrud, A.L., 2000. Competing models of entrepreneurial intentions. Journal of Business Venturing 15, 411-432.

Masoomi, E., Zamani, N., Bazrafkan, K., Reza, M., 2016. An investigation of the factors influencing entrepreneurial intention of senior agricultural students at Shiraz Univerity, Iran. International Journal of Agricultural Management and Development 6, 431-437.
Mohamed, Z., Rezai, G., Shamsudin, M.N., Mahmud, M.M., 2012. Enhancing young graduates' intention towards entrepreneurship development in Malaysia. Education + Training 54, 605-618.

Mohavedi, R., Latifi, S., Sayyar, L.Z., 2013. The factors affecting agricultural students attitude towards selfemployment and entrepreneurship. International Journal of Agriculture and Crop Sciences 5, 1813-1819.

Muhammad, A.D., Aliyu, S., Ahmed, S., 2015. The clute institute entrepreneurial intention among Nigerian university students. American Journal of Business Education 8, 239-247.

Peterman, N.E., Kennedy, J., 2003. Enterprise education: influencing students' perceptions of entrepreneurship. Entrepreneurship Theory and Practice 28, 129-144.

Pouratashi, M., 2014. Entrepreneurial Intentions of Agricultural Students: Levels and Determinants. The Journal of Agricultural Education and Extension, 1-11.

Pribadi, H., 2005. Defining and constructing the teaching model of entrepreneur education based on entrepreneurial intention model. Jurnal Teknik Industri 7, 76-82.

Ridha, R.K., Burhanuddin., Qahyu, B.P., 2016. Entrepreneurship intention in agricultural sector of young generation in Indonesia. Asia Pacific Journal of Innovation and Entrepreneurship 11, 76-89.

Saheed, A., Kavoos, M., 2016. The present attitude of African youth towards entrepreneurship. International Journal of Small Business and Entrepreneurship Research 4, 21-38.

Shapero, A., 1984. Why entrepreneurship? Working paper, Babson College.

Shiri, N., Davoud, M., Seyed, H., 2012. Entrepreneurial intention of agricultural students: effects of role model, social support, social norms and perceived desirability. Archives of Applied Science Research 4, 892-897.

Shiri, N., Shinnar, R.S., Mirakzadeh, A.A., Zarafshani, K., 2017. Cultural values and entrepreneurial intentions among agriculture students in Iran. International Entrepreneurship Management Journal. DOI 10.1007/ s11365-017-0444-9

Tkachev, A., Kolvereid, L., 1999. Self-employment intentions among Russian students. Entrepreneurship and Regional Development 11, 269-280.

Turker, D., Selcuk, S.S., 2009. Which factors affect entrepreneurial intention of university students? Journal of European Industrial Training 33, 142-159.

Urbano, D., Aparicio, S., Audretsch, D., 2018. Twenty-five years of research on institutions, entrepreneurship, and economic growth: what has been learned? Small Business Economics.

Wijerathna, R.M.S., 2015. Factors predicting the intention of academics of faculties of agriculture in the state universities in Sri Lanka to engage in outreach activities. Tropical Agricultural Research 26, 285-293. 
Yusoff, A., Ahmad, N.Z., Halim, H.A., 2016. Entrepreneurial orientation and agropreneurial intention among Malaysian agricultural students: The impact of agropreneurship education. Advances in BusinessRelated Scientific Research Journal 7, 77-92.

Zampetakis, L., Anagnosti, A., Anagnosti, A., 2014. Understanding entrepreneurial intentions of students in agriculture and related sciences. Poster paper prepared for presentation at the EAAE 2014 Congress 'Agri-Food and Rural Innovations for Healthier Societies', Ljubljana, August 26-29.

Zhang, Y., Duysters, G., Cloodt, M., 2014. The role of entrepreneurship education as a predictor of university students' entrepreneurial intention. International Entrepreneurship Management Journal 10, 623-641. 